\title{
Hydrogeochemical investigation of the origin of Molybdenum (Mo) in groundwater resources in Wadi Al Arab area, Northern Jordan
}

\section{Analisi idrogeochimica sull'origine del Molibdeno (Mo) nelle acque sotterranee dell'area di Wadi Al Arab, a nord della Giordania}

\author{
Ali R. El-Naqa, Khalil M. Ibrahim, Malik Abu Alrous
}

\begin{abstract}
Riassunto: Sono state rilevate concentrazioni elevate di Mo nell'acqua potabile estratta da pozzi domestici nell'area di Wadi Al Arab, vicino alla città di Irbid, a nord della Giordania. Il principale obiettivo di questo studio è di analizzare i processi idrogeochimici responsabili del rilascio di Mo nelle acque sotterranee. Di solito il Mo è un metallo naturalmente presente nella crosta terrestre. Tuttavia, la presenza di Mo nelle acque sotterranee rappresenta un potenziale problema di inquinamento.

Per raggiungere gli obiettivi di questo studio sono stati raccolti 34 campioni di acque sotterranee dall'intero bacino di Wadi Al Arab. Questi campioni sono stati analizzati utilizzando ICP-MS per il Mo totale e per gli altri principali cationi, anioni e metalli pesanti. I risultati ottenuti dall'analisi idrogeochimica mostrano che le acque sotterranee nel bacino di Wadi Al Arab sono suscettibili alla contaminazione da Mo a seguito di reazioni chimiche tra l'acqua e la sottostante formazione rocciosa ricca di argille, costituita principalmente da scisti e marne. I valori di concentrazione misurati sui pozzi testati variano da 46.6
\end{abstract}

Keywords: Mo, drinking water, Geochemical modeling, speciation, Jordan.

Parole chiave: Mo, acqua potabile, modellistica geochimica, speciazione, Giordania

\author{
Ali R. EL-NAQA 豐: \\ Faculty of Natural Resources and Environment, Hashemite University, Zarqa, \\ 13115, P. O. Box 150459, Jordan \\ elnaqa@hu.edu.jo
}

\section{Khalil M. IBRAHIM}

Department of Earth and Environment Sciences, Hashemite University, Zarqa, 13115, P. O. Box 150459, Jordan

Ibrahim@hu.edu.jo

Malik Abu ALROUS

Water Quality Supervisor at Pepsi Co., Zarqa, Jordan

Ricevuto/Received: 09 August 2018-Accettato/Accepted: 17 September 2018 Pubblicato online /Published online: 27 September 2018

This is an open access article under the CC BY-NC-ND license: http://creativecommons.org/licenses/by-nc-nd/4.0/

(C) Associazione Acque Sotterranee 2018 $\mu \mathrm{g} / \mathrm{L}$ a $1438.7 \mu \mathrm{g} / \mathrm{L}$, con un valore medio di $397.6 \mu \mathrm{g} / \mathrm{L}$. Pertanto, circa il $70 \%$ dei campioni d'acqua analizzati mostrano livelli di Mo che eccedono il limite di $70 \mu \mathrm{g} / \mathrm{L}$ per l'acqua potabile secondo l'Organizzazione Mondiale della Sanità.

I risultati della modellistica geochimica utilizzando il software VISUAL MINTEQ mostrano che la specie più abbondante di Mo minerale è lo ione molibdato $\left(\mathrm{MoO}_{4}{ }^{2-}\right)$, con una concentrazione di $30 \mu \mathrm{g} / \mathrm{L}$, che rappresenta più del $50 \%$ delle specie di Mo disciolte nelle acque sotterranee. La possibile sorgente di Mo nelle acque sotterranee del bacino di Wadi Al Arab è legata alla presenza di scisti bituminosi e fosfati all'interno della successione geologica dell'acquifero. Attraverso il modello geochimico sono stati calcolati gli indici di saturazione dei comuni minerali di Mo. Gli indici di saturazione calcolati hanno mostrato che le acque sotterranee sono sotto-saturate rispetto al Mo minerale, il che dimostra che l'equilibrio naturale non verrà mai raggiunto

Abstract: High Mo concentrations have been detected in drinking water pumped from domestic water supply wells located in the Wadi Al Arab area, at the Irbid city, northern Jordan. The main objective of this study is to investigate bydrogeochemical processes responsible for the release of $M_{0}$ in the groundwater resources. Usually $M_{0}$ is a metallic element that is naturally present in the earth's crust. However, the presence of Mo in groundwater is an important potential pollution issue.

To achieve the objectives of the study, 34 water samples were collected from the whole catchment area of Wadi Al Arab and were analyzed using ICP-MS for total Mo and the other major cations, anions and heavy metals. The results obtained from the hydrogeochemical investigation show that the groundwater in Wadi Al Arab catchment area is susceptible to Mo contamination due to the chemical reactions of water with clay-rich underlying bedrock that consists mainly of shale and marl rocks. The concentration values measured at the tested wells vary from $46.6 \mu \mathrm{g} / \mathrm{L}$ to $1438.7 \mu \mathrm{g} / \mathrm{L}$, with an average value of 397.6 $\mu \mathrm{g} / \mathrm{L}$. Therefore, about $70 \%$ of the analyzed water samples show Mo levels that exceed the permissible limit of $70 \mu \mathrm{g} / \mathrm{L}$ for drinking water according to World Health Organization.

The results of geochemical modeling using VISUAL MINTEQ software show that the most abundant species of Mo mineral is molybdate ion (MoO42-), with a concentration of $30 \mu \mathrm{g} / \mathrm{L}$, which accounts for more than $50 \%$ of the Mo species dissolved in groundwater. The possible source of the Mo in the groundwater in Wadi Al Arab catchment area is due to presence of oil shale and phosphate layers within the geological succession of the aquifer. Through the geochemical model, the saturation indices of the common Mo minerals were calculated. The calculated saturation indices showed that groundwater is under-saturated with respect to Mo mineral speciation, which emphasizes that natural equilibrium will never be reached. 


\section{Introduction}

Mo is a metal is used for modern technologies and industries. Mo is believed to be an essential element for human health well-being (Eisler 2000) and it can be toxic at concentrations exceeding $200 \mu \mathrm{g} / \mathrm{L}$. WHO (1993) introduced a guideline value for Mo for water used for drinking of $70 \mu \mathrm{g} / \mathrm{L}$.

Mo can be considered as an important nutrient for biological functions in animals, plants and microorganisms (BGS 2008; Harkness et al 2017). It also forms a vital component for enzymes that catalyze redox reactions (Stiefel 1996). Mo interacts usually with $\mathrm{Cu}$ and $\mathrm{SO}_{4}$ in organisms and the interaction between these compounds can lead to Mo deficiency and excess problems in biological systems.

Mo is an element which has several oxidation states that varies from -2 to 5 , however, the predominant states in nature are $\mathrm{Mo}^{4+}$ and $\mathrm{Mo}^{5+}$. As the Mo has variable oxidation states, this means that it is involved in a number of redox reactions. Mo has several naturally isotopes such as: ${ }^{92} \mathrm{Mo}$, ${ }^{94} \mathrm{Mo},{ }^{95} \mathrm{Mo},{ }^{96} \mathrm{Mo},{ }^{97} \mathrm{Mo}$ and ${ }^{98} \mathrm{Mo}$. The ${ }^{98} \mathrm{Mo}$ is the most abundant isotope which accounts for $24 \%$. In addition, the Mo is strongly chalcophile and its behavior is similar to sulfur and has similar properties to tungsten and vanadium.

Mo does not occur as a free element in nature and is generally found in association with oxygen sulfur, tungsten, uranium, lead, iron, magnesium, vanadium, cobalt, bismuth, or calcium. Smedley and Kinniburgh (2017) provide a comprehensive review of Mo in groundwater and natural waters. Mo forms a major constituent in the sulfide minerals molybdenite $\left(\left(\mathrm{MoS}_{2}\right)\right.$ and the oxides such as wulfenite $\left(\mathrm{PbMoO}_{4}\right)$. It also presents at variable concentrations in other sulfide minerals including pyrite $\left(\mathrm{FeS}_{2}\right)$, galena $(\mathrm{PbS})$ and sphalerite $(\mathrm{ZnS})$. Mo is widely disseminated in the environment: its abundance in the Earth's crust is estimated to be $1-1.5 \mathrm{mg} / \mathrm{kg}$ (Wedepohl 1995).

Abed et al. (2009) reported Mo in oil-bearing carbonates from Jordan in the range 60 to $173 \mathrm{mg} / \mathrm{kg}$; Al Kuisi et al. (2015) reported contents in the range 0.93 to $34.7 \mathrm{mg} / \mathrm{kg}$ (mean $11.7 \mathrm{mg} / \mathrm{kg}$ ) for Upper Cretaceous oil shales deposits. The Mo in the Jordanian oil-bearing rocks was believed to be mainly associated with organic matter rather than sulfides (Al Kuisi et al. 2015).

The dissolved Mo in natural water depends on its geochemistry. It is tied to $\mathrm{pH}$ and redox potential in the groundwater. At $\mathrm{pH}$ levels above 5, the presence of $\mathrm{Mo}$ in groundwater is expected to occur mostly as molybdate ion, $\left(\mathrm{MoO}_{4}{ }^{2-}\right)$ (Hem 1989). Under certain specific geochemical conditions $\mathrm{Mo}$ in groundwater may become occluded to mineral oxides (iron, manganese, aluminum) or soil clay minerals, or may precipitate as solid mineral deposits. Mo adsorption to clay minerals has been shown to take place at relatively low $\mathrm{pH}$ levels (maximum around $\mathrm{pH}=3$ ), while adsorption to metal oxide minerals has been shown to take place at higher $\mathrm{pH}$ levels (approximate $\mathrm{pH}$ range of 4 to 8).

Wadi Al Arab well field is the major source of potable water for the city of Irbid and these wells are located in the Wadi Al Arab area at the Northern tip of Jordan near the Yarmouk River. This research will be focused on the study of possible contamination of groundwater in Wadi Al Arab well field by heavy metal, because of elevated Mo concentrations that have been found in several wells used for water supply (Al Kuisi et al. 2015, Ibrahim et al. 2016).

\section{Description of the study area}

Wadi El-Arab catchment area is located in northern Jordan, on the border with Syria (Figure 1). It extends from $747000 \mathrm{~m}$ to $770000 \mathrm{~m}$ in the west-east direction and from $3596000 \mathrm{~m}$ to $3618000 \mathrm{~m}$ in the south-north direction (UTM, WGS84, zone $36 \mathrm{~N}$ ). The catchment area extends for about $267 \mathrm{~km}^{2}$. The general shape of the basin is oval with the longer axis, oriented SE-NW direction. The general slope of the area is from east to west. The highest elevation in Wadi Al Arab basin is about $850 \mathrm{~m}$ above mean sea level ( $\mathrm{msl}$ ) near Irbid City and the lowest elevation is $-126 \mathrm{~m} \mathrm{msl}$ at the riverbed of

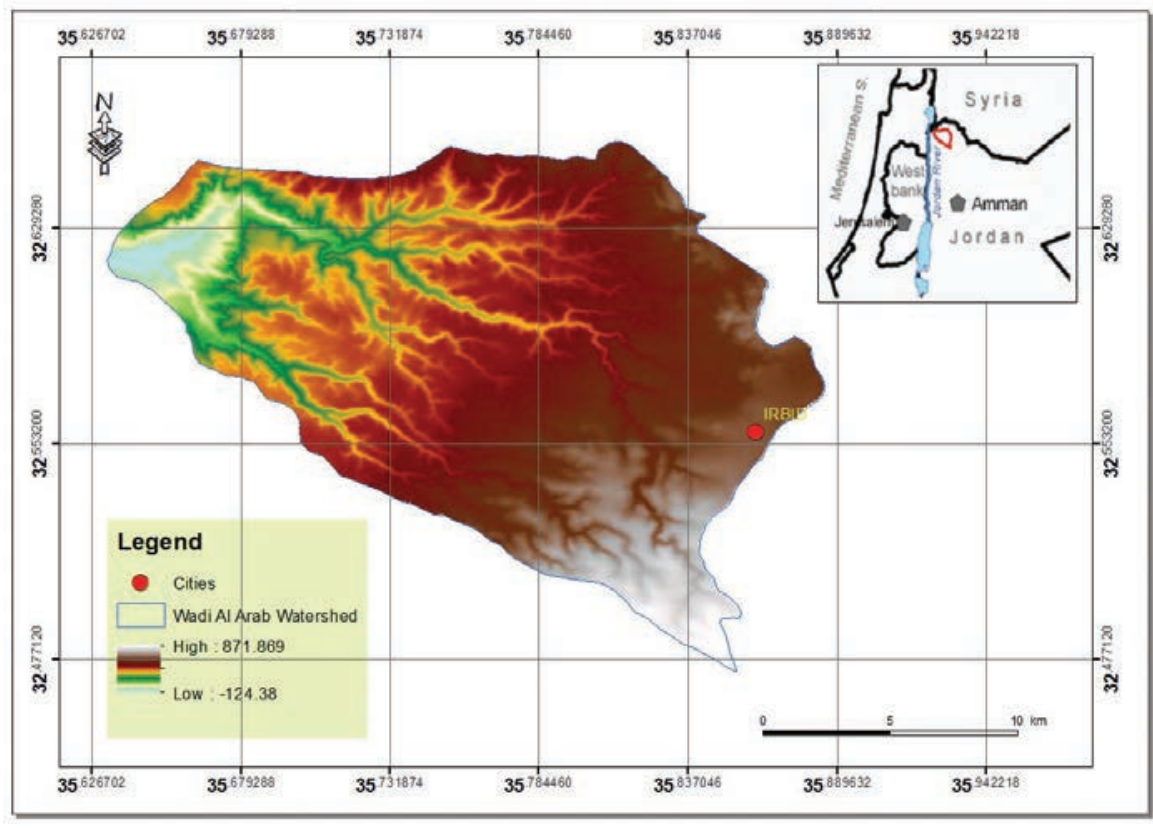

Fig. 1 - Location map of Wadi Al Arab catchment area, northern Jordan.

Fig. 1 - Mappa di ubicazione del bacino di Wadi Al Arab, a nord della Giordania. 
Wadi Al Arab dam site.

Wadi Al Arab flows through a deep V-shaped valley. The average annual precipitation ranges from $500 \mathrm{~mm}$ over the western highlands of Irbid City, to $350 \mathrm{~mm}$ in the Jordan Valley (North Shouneh). The Wadi Al Arab well field is located in the northwestern part of Jordan. It forms an important source for drinking water supply of Irbid City and many villages in the northern highland.

This study will attempt to investigate all possible reasons that might lead to increase the concentration of Mo in groundwater. Furthermore, geochemical modeling will be used to identify the occurrence of relevant Mo species that might result from water-rock interaction processes.

\section{Geological setting of the Wadi AI Arab area}

The stratigraphy and structural set up of the Wadi Al Arab area is to a great extent reflected by its topography. The basin is characterized by Upper Cretaceous and Lower Tertiary limestones, marls, shales and dolomites. In many places, the Cretaceous and Tertiary beds are overlain by Quaternary gravels and terrace deposits. The basin is drained by the northward flowing tributaries of the Yarmouk River. The generalized geological map for Wadi Al-Arab catchment area is shown in Figure 2. Description of each geological units of the study area is reported in Table 1.

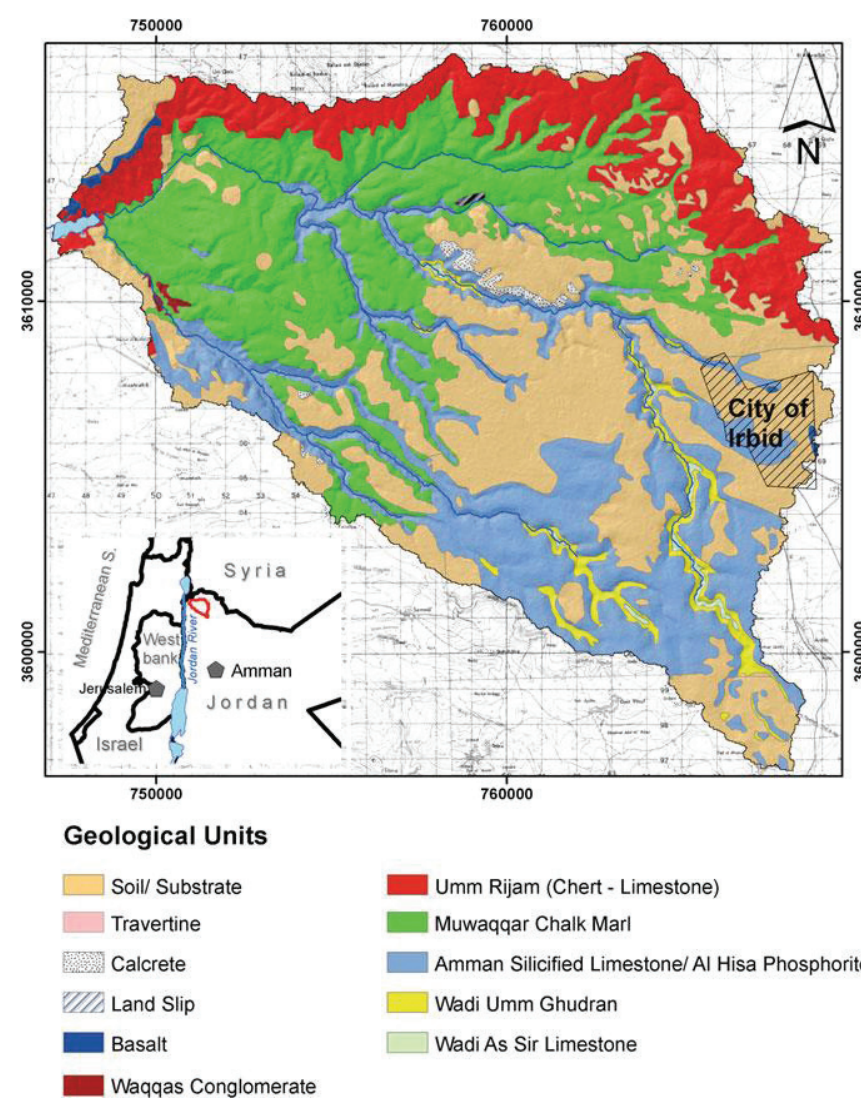

Fig. 2 - Geological map of Wadi Al Arab catchment area (MWI, 2012).

Fig. 2 - Carta geologica del bacino di Wadi Al Arab (MWI, 2012).

\section{Hydrogeology}

The Wadi Es-Sir (A7) and the Amman formations (B2) referred to as B2/A7 aquifer system is the major aquifer in Wadi Al-Arab area. The groundwaters of this catchment are under confined to unconfined conditions. There are fourteen wells in Wadi Al-Arab, taping the aquifer at various depths. In addition, five springs occur in the same aquifer while another spring is in B3 aquifer and one well is drilled in B2 aquifer. All wells drilled in the study area were originally flowing under artesian conditions, then as a result of over pumping most of these wells ceased to flow. The geological formations in Wadi Al Arab is subdivided into hydrogeologic units, which form aquifers and aquicludes (Figure 3).

The hydrogeology of the area is affected by the geological structures, which have considerable effect on the groundwater occurrence and movement. It has been found that the dominant factor in determining the potentially water-bearing areas is the permeability and secondary porosity both of which are directly related to the structural conditions (MacDonald 1965). Groundwater occurs mostly in limestone, fractured chert, sandstone rocks and fluvial deposits.

The B2/A7 is often considered as a single hydraulic complex at the regional scale. It is a very important aquifer system in the study area, because of its high productivity and extent of the Upper Cretaceous carbonate rocks, which largely outcrops in the northern high lands, where the highest recharge rates occur.

According to WAJ (1989), the transmissivity of the B2/A7 aquifer ranges from $9 \mathrm{~m}^{2} /$ day to more than $900 \mathrm{~m}^{2} /$ day. The storage coefficient of this aquifer in the confined condition varies from $10^{-3}$ to $10^{-5}$, while the specific capacity varies from less than $0.01 \mathrm{~L} / \mathrm{s} / \mathrm{m}$ to more than $50 \mathrm{~L} / \mathrm{s} / \mathrm{m}$ (WAJ 1989). The permeability ranges from 0.01 to more than $100 \mathrm{~m} /$ day (WAJ 1989).

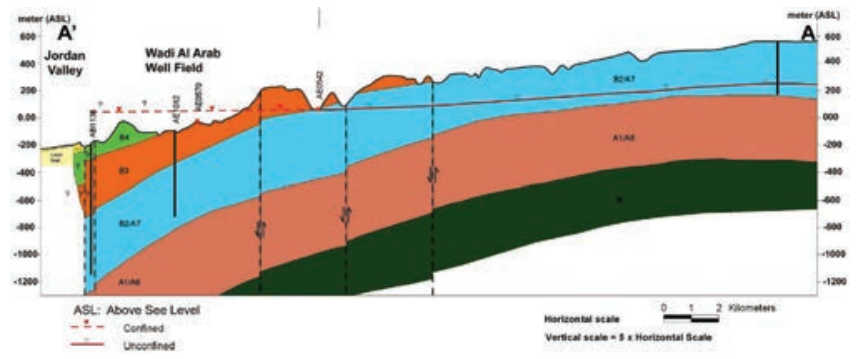

Fig. 3 - Hydrogeological cross section (Margana 2006).

Fig. 3 - Sezione idrogeologica (Margana 2006).

\section{Groundwater dynamics}

The B2/A7 outcrops in the eastern and southern border of the catchment, where direct recharge occurs. Figure 4 was obtained by interpolation of groundwater level measured at the observation wells located within the catchment. This Figure indicates that the groundwater flow direction occurs from south towards northwest to Wadi Al Arab and Yarmouk River where most of the discharge occurs. 


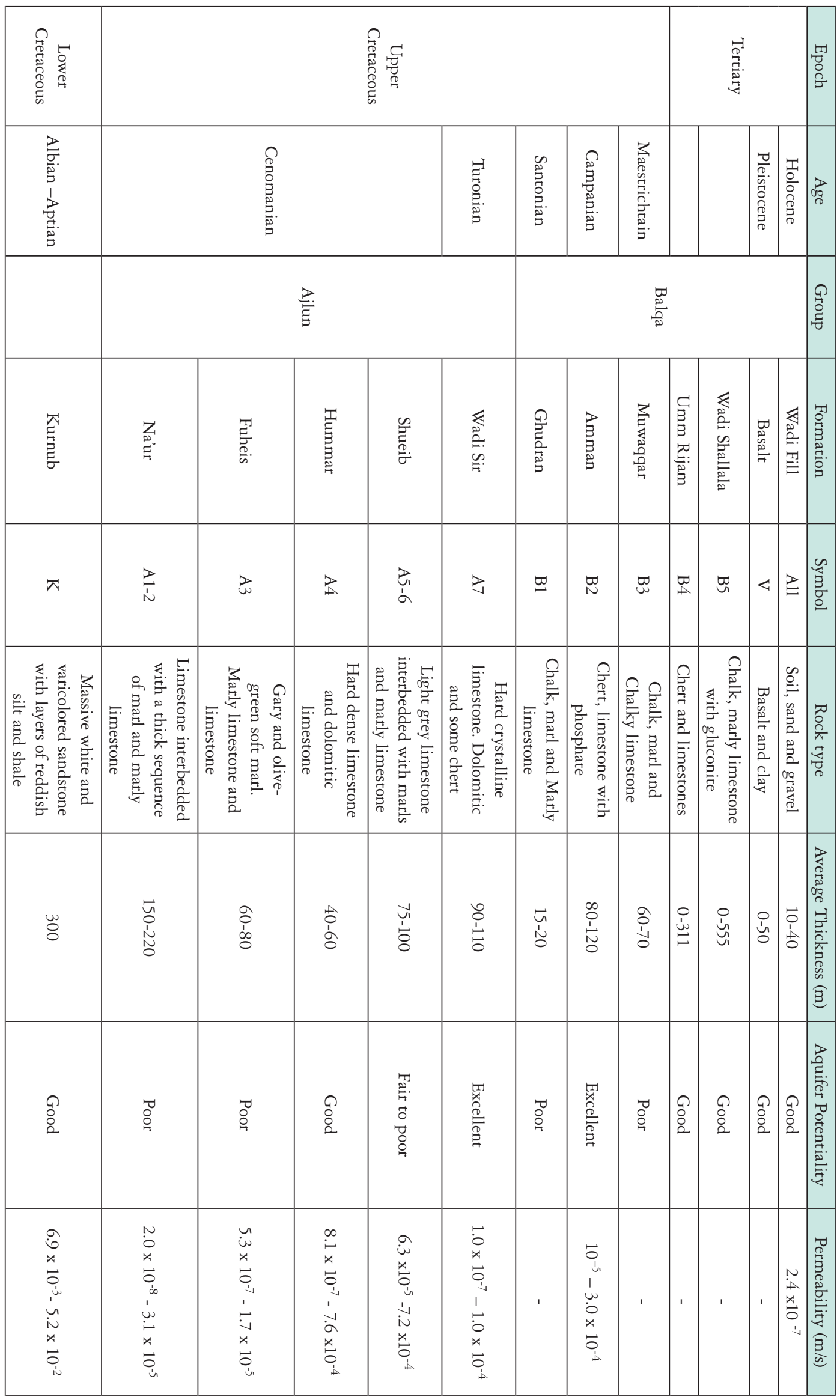




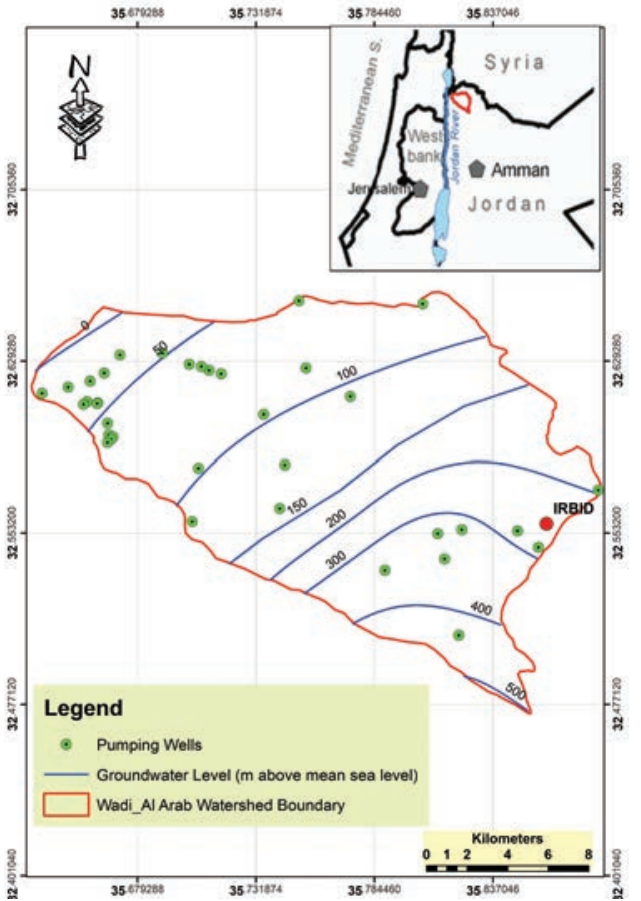

Fig. 4 - Groundwater flow direction map of the B2/A7 aquifer in Wadi Al Arab catchment area.

Fig. 4 - Direzione del flusso delle acque sotterranee dell'acquifero B2/A7 nel bacino di Wadi Al Arab.

\section{Materials and methods}

A number of governmental water supply wells in Wadi Al Arab provide water containing Mo and other heavy metals at concentrations above the Jordanian drinking water quality standards (JISM, 2008). A water sampling campaign at these fields was carried out during September 2017. Thirty-four samples were collected from Wadi Al Arab well field and the adjacent areas. All samples were collected from the B2/A7 aquifer, which is the main water source for drinking water in northern Jordan.

The water samples were collected in $1000 \mathrm{~mL}$ polyethylene bottles for routine inorganic chemical analysis. The in situ measured parameters are Electrical Conductivity (EC), temperature $\left(\mathrm{C}^{\circ}\right), \mathrm{pH}$, Dissolved Oxygen (DO), Total Dissolved Solid (TDS), redox potential (Eh) and turbidity (NTU).

\section{Results and discussion In situ measured parameters}

Groundwater temperature was measured in the field and was found to be varied from 26.0 to $28.0 \mathrm{C}^{\circ}$, with an average value of $27.0^{\circ} \mathrm{C}$. The $\mathrm{pH}$ was measured using in situ Hanna $\mathrm{pH}$ probe and varied from 7.61 to 7.10 with an average value of 7.38. The Eh was measured within a range of -35 to -7 $\mathrm{mV}$, with an average value of $-18.27 \mathrm{mV}$. EC ranges between $760-984 \mu \mathrm{S} / \mathrm{cm}$, with an average value of $820.40 \mu \mathrm{S} / \mathrm{cm}$. Turbidity was measured within a range of 0.13 to 0.99 NTU, with an average value of $0.58 \mathrm{NTU}$, and DO was measured within a range of 1.20 to $5.8 \mathrm{mg} / \mathrm{L}$. Table 2 shows a statistical summary of field measured parameter for all the wells.

\section{Chemical composition of groundwater}

The statistics of the chemical composition for the sampled water are given in Table 3. Bicarbonate concentrations show moderate values ranging from $199.14 \mathrm{mg} / \mathrm{L}$ to 474.43 $\mathrm{mg} / \mathrm{L}$, with an average value of $414.01 \mathrm{mg} / \mathrm{L}$. Calcium and magnesium also show moderate values between $90.43 \mathrm{mg} / \mathrm{L}$ and $113.69 \mathrm{mg} / \mathrm{L}$ and $34.43 \mathrm{mg} / \mathrm{L}$ and $45.76 \mathrm{mg} / \mathrm{L}$, respectively, with average values of $104.72 \mathrm{mg} / \mathrm{L}$ and $38.22 \mathrm{mg} / \mathrm{L}$. The main source for these ions is the dissolution reaction in the carbonate aquifer. The $\mathrm{Mg} / \mathrm{Ca}$ weight ratio reflects the dolomitic type of the $\mathrm{A} 4$ aquifer with values ranging between 0.21 and 0.74 and with an average value of 0.55 .

Naturally, sodium is introduced in groundwater by dissolution of halite and secondary during ion exchange reactions with surfaces of some clay minerals, replacing calcium or magnesium. Sulphate ion is introduced into groundwater during gypsum or anhydrite dissolution, respectively. However, the concentration of these ion ranges in the observed wells from $21.9 \mathrm{mg} / \mathrm{L}$ to $38.1 \mathrm{mg} / \mathrm{L}$, with an average value of $25.9 \mathrm{mg} / \mathrm{L}$. Potassium is measured at low to moderate concentrations ranging from $2.39 \mathrm{mg} / \mathrm{L}$ to 4.66 $\mathrm{mg} / \mathrm{L}$, with an average value of $2.99 \mathrm{mg} / \mathrm{L}$.

Nitrate concentrations, which may reflect water pollution by fertilizers and irrigation (Wang et al. 2015), were found to be moderate, ranging from $15 \mathrm{mg} / \mathrm{L}$ to $45 \mathrm{mg} / \mathrm{L}$, with an average value of $29.78 \mathrm{mg} / \mathrm{L}$. Sulfate usually occurs naturally in groundwater because the water dissolves it out of rocks. Sulfate concentration ranges from $94.11 \mathrm{mg} / \mathrm{L}$ to 110.31 $\mathrm{mg} / \mathrm{L}$, with an average value of $101.07 \mathrm{mg} / \mathrm{L}$.

Tab. 2 - Statistical analysis of feld parameters.

Tab. 2 - Analisi statistica dei parametri di campo.

\begin{tabular}{|l|c|c|c|c|c|c|}
\hline Parameter & Unit & Min & Max & Average & Median & St. Dev. \\
\hline $\mathrm{pH}$ & unit & 7.10 & 7.61 & 7.38 & 7.35 & 0.14 \\
\hline $\mathrm{Eh}$ & $\mathrm{mV}$ & -35.00 & -7.00 & -18.27 & -16.60 & 8.44 \\
\hline $\mathrm{EC}$ & $\mu \mathrm{S} / \mathrm{cm}$ & 760 & 984 & 820.40 & 810 & 85.68 \\
\hline Temp & $\mathrm{C}^{\circ}$ & 26.00 & 28.00 & 27.38 & 27.00 & 0.65 \\
\hline Turbidity & $\mathrm{NTU}$ & 0.13 & 0.99 & 0.58 & 0.52 & 0.29 \\
\hline DO & $\mathrm{mg} / \mathrm{L}$ & 1.20 & 5.80 & 3.44 & 2.66 & 1.72 \\
\hline
\end{tabular}


Tab. 3 - Statistical analysis of chemical composition for the sampled water.

Tab. 3 - Analisi statistica della composizione chimica dell'acqua campionata

\begin{tabular}{|l|c|c|c|c|}
\hline $\begin{array}{c}\text { Parameter } \\
(\mathrm{mg} / \mathrm{L})\end{array}$ & Min & Max & Average & St. Dev. \\
\hline $\mathrm{HCO}_{3}$ & 199.14 & 474.43 & 414.01 & 2.11 \\
\hline $\mathrm{Ca}$ & 90.43 & 113.96 & 104.72 & 6.13 \\
\hline $\mathrm{Mg}$ & 34.34 & 45.76 & 38.22 & 3.06 \\
\hline $\mathrm{K}$ & 2.39 & 4.66 & 2.99 & 0.56 \\
\hline $\mathrm{Na}$ & 21.88 & 38.52 & 25.94 & 4.33 \\
\hline $\mathrm{NO}_{3}$ & 15.00 & 41.00 & 29.78 & 6.57 \\
\hline $\mathrm{SO}_{4}$ & 94.11 & 128 & 101.07 & 4.76 \\
\hline $\mathrm{Cl}$ & 44.00 & 59.00 & 49.00 & 4.95 \\
\hline
\end{tabular}

Figure 5 shows the plotted major cations and anions of the analyzed samples on a Piper diagram to determine the hydrochemical facies and water types. Such water has temporary hardness and can be classified as $\mathrm{Ca}, \mathrm{Mg}-\mathrm{HCO}_{3}$ type and $\mathrm{Ca}-\mathrm{Na}-\mathrm{HCO}_{3}$ type. This type is mostly present in the areas of Wadi Al Arab and Irbid. Detailed classification of water types using Piper plot illustrates similar water types (Ca, $\mathrm{Mg}-\mathrm{HCO}_{3}$ type) in Irbid and Wadi Al Arab area. While the southeastern part of the study area is of $\mathrm{Na}_{2} \mathrm{SO}_{4}$ type (Figure 5). The quality of water in the B2/A7 aquifer is significantly influenced by $\mathrm{Ca}-\mathrm{HCO}_{3}$ type, indicating recharge from the near Ajlun and Irbid regions.

\section{Concentration of heavy metals in groundwater}

Over the total 34 wells, 14 wells exhibit higher concentrations of the analyzed heavy metals when compared with national and international standards for drinking water. $\mathrm{Mo}, \mathrm{Ni}, \mathrm{Si}$, Fe and U show values exceeding WHO (2011) and Jordanian

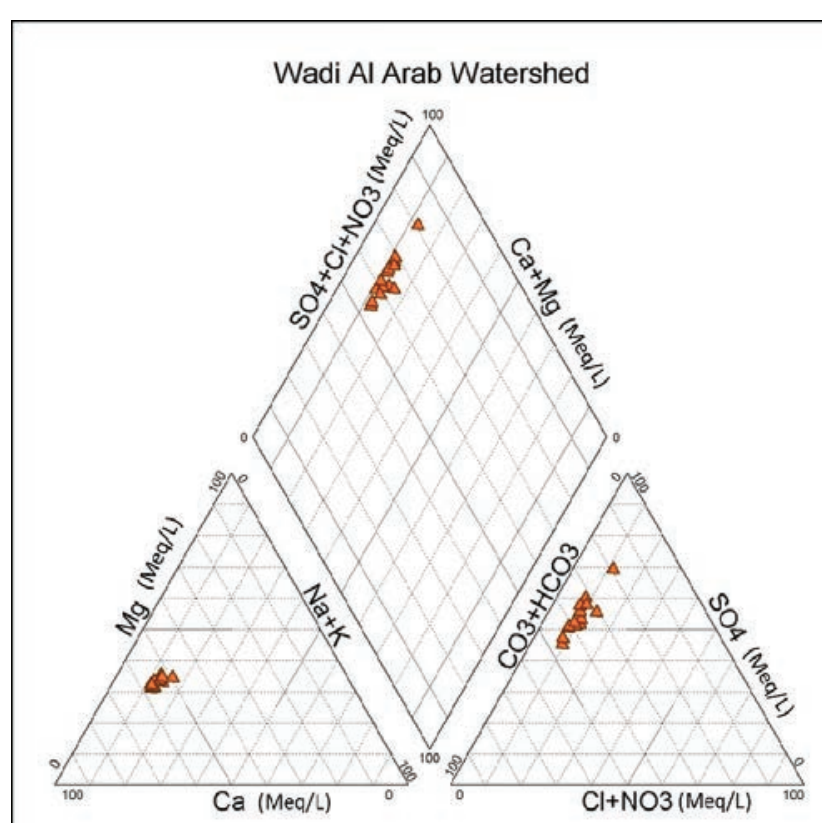

Fig. 5 - Piper diagram of the major cations and anions of tested wells.

Fig. 5 - Diagramma di Piper dei principali cationi e anioni dei pozzi testati. standards (JISM,2008). Mo is one of the major contaminants in the studied area. A summary of the concentration of the heavy metals is presented in Table 4.

Tab. 4 - Statistical analysis of chemical composition for the sampled water.

Tab. 4 - Analisi statistica della composizione chimica dell'acqua campionata.

\begin{tabular}{|l|c|c|c|c|c|c|c|}
\hline $\begin{array}{l}\text { Parameter } \\
(\mathrm{mg} / \mathrm{L})\end{array}$ & Min & Max & Average & Median & $\begin{array}{c}\text { St. } \\
\text { Dev. }\end{array}$ & $\begin{array}{c}\text { JISM } \\
286 / 2008\end{array}$ & $\begin{array}{c}\text { WHO } \\
(1997)\end{array}$ \\
\hline $\mathrm{Mo}$ & 0.04 & 1.43 & 0.39 & 0.37 & 0.36 & 0.070 & 0.070 \\
\hline $\mathrm{Ni}$ & 0.02 & 0.16 & 0.078 & 0.06 & 0.05 & 0.070 & 0.020 \\
\hline $\mathrm{Si}$ & 9.43 & 10.87 & 9.97 & 9.96 & 0.35 & 0.020 & - \\
\hline $\mathrm{Sr}$ & 0.47 & 1.036 & 0.67 & 0.66 & 0.14 & 0.010 & - \\
\hline $\mathrm{U}$ & 0.01 & 0.03 & 0.015 & 0.008 & 0.01 & 0.010 & 0.015 \\
\hline
\end{tabular}

\section{Mo analysis}

Mo was analyzed using the ICP-MS method., It Mo was detected in all the analyzed samples with concentrations ranging between $0.04 \mathrm{mg} / \mathrm{L}$ and $1.43 \mathrm{mg} / \mathrm{L}$ and with an average value of $0.39 \mathrm{mg} / \mathrm{L}$ (Figure 6). The spatial distribution of Mo concentration in the study area was carried out using ordinary kriging techniques as shown in Figure 7. The higher Mo concentrations are present in the northwestern part of the Wadi Al Arab catchment area, where it reaches a value of $1384.6 \mu \mathrm{g} / \mathrm{L}$. The Mo concentration increases along the groundwater flow direction towards the northwestern part of Wadi Al Arab catchment area. These areas contain groundwater with Mo concentrations greater than the Jordanian Standards for drinking Water and WHO (2011) drinking water guideline

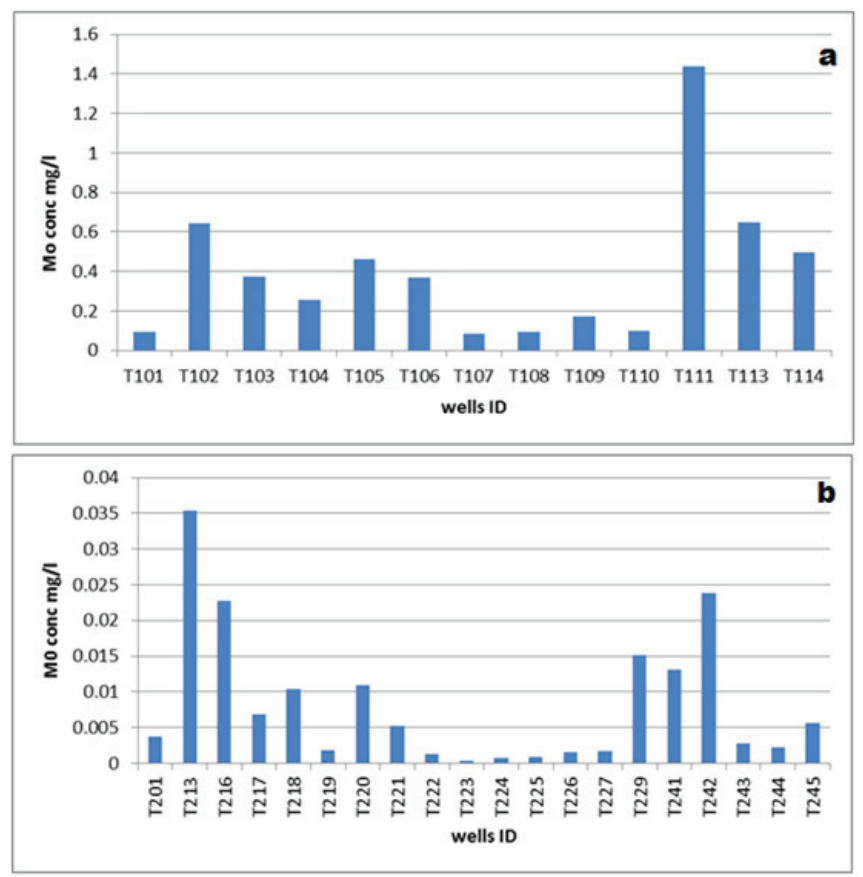

Fig. 6 - Concentration of Mo in the tested wells (Wadi Al Arab wells).

Fig. 6 - Concentrazione di Mo nei pozzi testati (pozzi di Wadi Al Arab). 


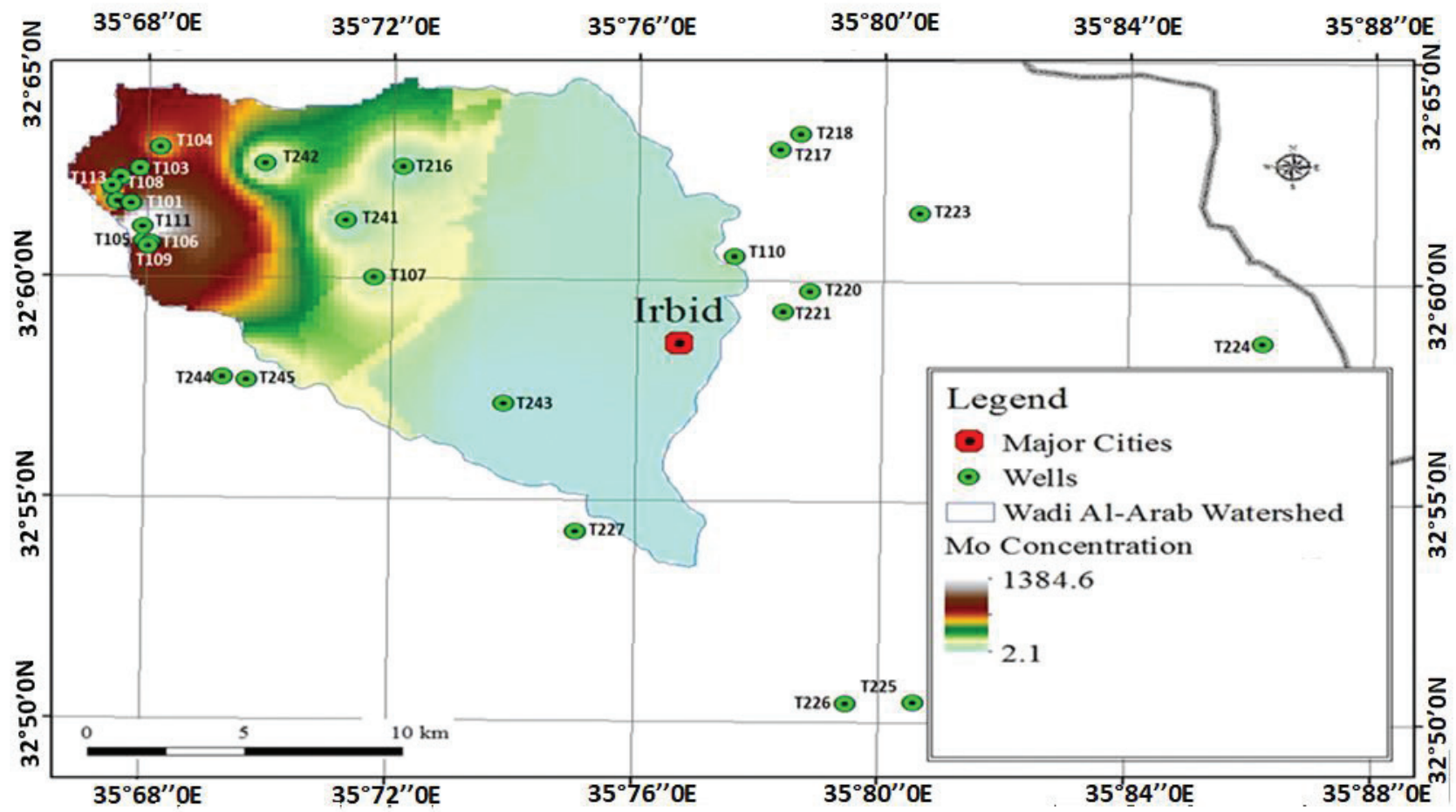

Fig. 7 - Distribution of Mo concentration in Wadi Al Arab area.

Fig. 7 - Distribuzione della concentrazione di Mo nell'area di Wadi Al Arab.

\section{Hydrogeochemical modeling}

For better understanding the chemical reactions during the water-rock interaction of the studied wells, the VISUAL MINTEQ software Ver. 3.1 (Gustafsson, 2014) was used to compute the mineral species of Mo and to calculate saturation indices of minerals constituting the aquifer matrix. The concentration of dissolved Mo in natural water samples is tied closely to $\mathrm{pH}$ and redox conditions in groundwater (Langmuir, 1997). At $\mathrm{pH}$ levels above 5, Mo in groundwater is expected to exist mostly as molybdate ion(MoO42-) (Smedley et al., 2014). Aquifer reduction/oxidation (redox) conditions can greatly affect the speciation and mobilization of Mo in groundwater (Lourigan and Phelps, 2013). Oxidizing conditions are characterized by the presence of relatively higher concentrations of redox parameters such as nitrate nitrogen, dissolved oxygen, and sulfate, while reducing conditions are characterized by relatively higher concentrations of redox sensitive parameters such as dissolved manganese, dissolved iron, and dissolved arsenic (Thomas, 2007).

The elevated Mo concentrations in groundwater in northern Jordan are attributed to water-oil shale interaction (Al Kuisi et al., 2015). Oil shale in Jordan is usually enriched with heavy metals including $\mathrm{Mo}, \mathrm{Cr}, \mathrm{Ni}$, Se, As, Cd, Zn, V and U (Abed and Amireh 1983; Abed et al. 2009). Consequently, Mo is associated with bituminous limestone and phosphate rock units of the study area which is released to groundwater wells (Al Kuisi et al., 2015).

\section{Geochemical speciation modeling.}

Thirty-four samples were used for hydrogeochemical modelling of concentration of metals and the $\mathrm{pH}$. The Mo speciation for the all tested wells is shown in Table 5. The concentration of Mo species is shown in Figure 8.

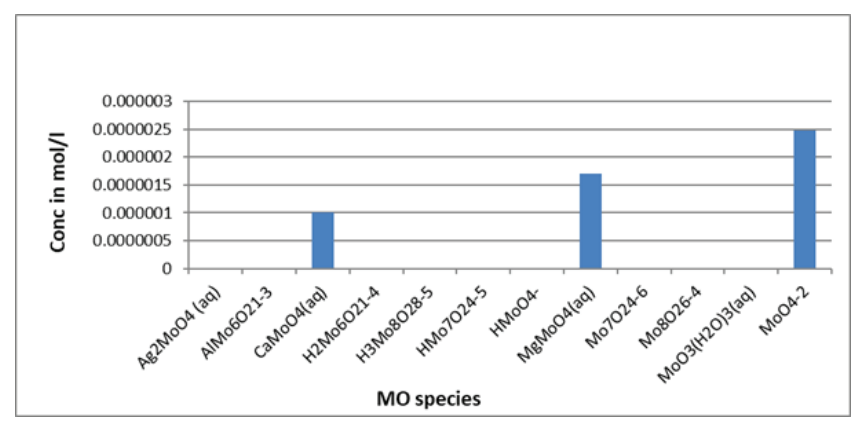

Fig. 8 - Concentration of the species of $M$ o.

Fig. 8 - Concentrazione delle specie di Mo.

\section{Mineral species modeling}

While studying the chemistry of groundwater, it is often necessary to express the extent of the chemical equilibrium between water and aquifer minerals (such as calcite, dolomite, halite, etc.) that are commonly involved in the reaction between water and the rock matrix. Some of these minerals dissolve congruently, meaning that the products of the mineral 
Tab. 5 - Concentration and activity of aqueous inorganic Mo species (molll).

Tab. 5 - Concentrazione e attività di specie acquose inorganiche di Mo (mol/l).

\begin{tabular}{|l|c|c|c|c|}
\hline \multicolumn{1}{|c|}{ Species } & Concentration & Activity & Log activity & $\begin{array}{c}\text { \% of total } \\
\text { concentration }\end{array}$ \\
\hline $\mathrm{Ag}_{2} \mathrm{MoO}_{4}(\mathrm{aq})$ & $9.88 \mathrm{E}-26$ & $9.91 \mathrm{E}-26$ & -25.004 & \\
\hline $\mathrm{CaMoO}_{4}(\mathrm{aq})$ & $7.79 \mathrm{E}-07$ & $7.82 \mathrm{E}-07$ & -6.107 & 19.2 \\
\hline $\mathrm{H}_{2} \mathrm{Mo}_{6} \mathrm{O}_{21}{ }^{-4}$ & $3.34 \mathrm{E}-39$ & $5.33 \mathrm{E}-40$ & -39.274 & \\
\hline $\mathrm{H}_{3} \mathrm{Mo}_{8} \mathrm{O}_{28}{ }^{-5}$ & $4.64 \mathrm{E}-79$ & $3.22 \mathrm{E}-80$ & -79.492 & \\
\hline $\mathrm{HMO}_{7} \mathrm{O}_{24}^{-5}$ & $4.11 \mathrm{E}-44$ & $2.33 \mathrm{E}-45$ & -44.632 & \\
\hline $\mathrm{HMoO}^{-4}$ & $7.89 \mathrm{E}-12$ & $7.09 \mathrm{E}-12$ & -11.149 & 0.096 \\
\hline $\mathrm{MgMoO}_{4}(\mathrm{aq})$ & $2.35 \mathrm{E}-07$ & $2.35 \mathrm{E}-07$ & -6.629 & 24.1 \\
\hline $\mathrm{Mo}_{7} \mathrm{O}_{24}^{-6}$ & $2.08 \mathrm{E}-42$ & $3.34 \mathrm{E}-44$ & -43.476 & \\
\hline $\mathrm{Mo}_{8} \mathrm{O}_{26}^{-4}$ & $2.55 \mathrm{E}-55$ & $4.07 \mathrm{E}-56$ & -55.39 & \\
\hline $\mathrm{MoO}_{3}\left(\mathrm{H}_{2} \mathrm{O}_{3}(\mathrm{aq})\right.$ & $3.87 \mathrm{E}-12$ & $3.88 \mathrm{E}-12$ & -11.412 & \\
\hline $\mathrm{MoO}_{4}^{-2}$ & $2.30 \mathrm{E}-06$ & $1.46 \mathrm{E}-06$ & -5.837 & 56.7 \\
\hline
\end{tabular}

dissolution reactions are all dissolved species. Many minerals dissolve incongruently, which means that the dissolution product may occur as minerals. The saturation index of water with respect to a certain mineral can be calculated by the following equation:

$$
S I=\log \left(\frac{I A P}{K_{S P}}\right)
$$

where IAP is the Ionic Activity Product of the appropriate ions and $K_{s p}$ is the solubility product of the minerals.

The importance of the saturation indices to determine rock interaction. if $\mathrm{SI}>0$ the water is oversaturated so the minerals is precipitated within the aquifer matrix. If the $\mathrm{SI}<0$ the water is undersaturated with respect to that mineral and the dissolution processes proceed and when the $\mathrm{SI}=0$ the reaction is at equilibrium, so the water is neither or nor precipitate or dissolve minerals from the aquifer matrix. In the current work, saturation indices of different Mo mineral species were calculated using the VISUAL MINTEQ software.

Variation in the chemistry of groundwater is mainly a function of the interaction between the groundwater and the composition of the aquifer lithology through which it moves.

The saturation indices of Mo species were calculated and tabulated in Table 6. The values of saturation indices of Mo species such as $\mathrm{CaMoO}_{4}(\mathrm{~s})(\mathrm{SI}=-1.517), \mathrm{CdMoO}_{4}(\mathrm{~s})$ (SI $=-2.258), \mathrm{CuMoO}_{4}(\mathrm{~s})(\mathrm{SI}=-3.427)$ and $\mathrm{MgMoO}_{4}(\mathrm{~s})(\mathrm{SI}=$ -7.809) are negative values as shown in Figure (9). This means that groundwater is under saturated conditions with respect to these Mo mineral species and that water has the capability to dissolve these minerals along the groundwater flow path. This indicates that groundwater has short residence times and natural equilibrium with Mo-mineral species is never reached (i.e., $\mathrm{SI}=0$ ). The $\mathrm{MoO}_{4}^{-2}$ mineral is highly soluble, and this could explain the presence of the elevated concentrations of Mo in drinking water in Irbid City.

Mo is metal-oxygen bond and a redox-sensitive metal and is
Tab. 6 - Saturation indices and Ion Activity Product (IAP) of Mo mineral species.

Tab. 6 - Indici di saturazione e Prodotto di Attività Ionica (IAP) delle specie minerali di Mo.

\begin{tabular}{|l|c|c|}
\hline \multicolumn{1}{|c|}{ Mineral } & Average of log IAP & $\begin{array}{c}\text { Average Saturation } \\
\text { index }\end{array}$ \\
\hline $\mathrm{Al}_{2}\left(\mathrm{MoO}_{4}\right)_{3}(\mathrm{~s})$ & -58.052 & -60.42 \\
\hline $\mathrm{BaMoO}_{4}(\mathrm{~s})$ & -12.972 & -6.012 \\
\hline $\mathrm{BeMoO}_{4}(\mathrm{~s})$ & -20.739 & -18.957 \\
\hline $\mathrm{CaMoO}_{4}(\mathrm{~s})$ & -9.467 & -1.517 \\
\hline $\mathrm{CdMoO}_{4}(\mathrm{~s})$ & -16.408 & -2.258 \\
\hline $\mathrm{CoMoO}_{4}(\mathrm{~s})$ & -16.47 & -8.709 \\
\hline $\mathrm{CuMoO}_{4}(\mathrm{~s})$ & -16.504 & -3.427 \\
\hline $\mathrm{H}_{2} \mathrm{MoO}_{4}(\mathrm{~s})$ & -24.095 & -11.219 \\
\hline $\mathrm{K}_{2} \mathrm{MoO}_{4}(\mathrm{~s})$ & -15.084 & -18.346 \\
\hline $\mathrm{Li}_{2} \mathrm{MoO}_{4}(\mathrm{~s})$ & -19.097 & -21.539 \\
\hline $\mathrm{MgMoO}_{4}(\mathrm{~s})$ & -9.659 & -7.809 \\
\hline $\mathrm{MoO}_{3}(\mathrm{~s})$ & -24.095 & -16.095 \\
\hline $\mathrm{Na}_{2} \mathrm{Mo}_{2} \mathrm{O}_{7}(\mathrm{~s})$ & -36.577 & -19.98 \\
\hline $\mathrm{Na}_{2} \mathrm{MoO}_{4}(\mathrm{~s})$ & -12.482 & -13.972 \\
\hline $\mathrm{Na}_{2} \mathrm{MoO}_{4}: 2 \mathrm{M}_{2} \mathrm{O}(\mathrm{s})$ & -12.482 & -13.706 \\
\hline $\mathrm{NiMoO}_{4}(\mathrm{~s})$ & -15.424 & -4.282 \\
\hline $\mathrm{PbMoO}_{4}(\mathrm{~s})$ & -17.254 & -1.634 \\
\hline $\mathrm{ZnMoO}_{4}(\mathrm{~s})$ & & -453 \\
\hline & & \\
\hline & -15.47 & -19 \\
\hline
\end{tabular}

easily formed and/or broken (McEwan et al. 2001). Therefore, the Mo-oxyanion complex $\left(\mathrm{MoO}_{4}^{-2}\right)$ requires very little energy and Mo has a high reducing potential. Reductive dissolution of $\mathrm{Fe}$ and $\mathrm{Mn}$ in sub oxic waters is responsible for releasing Mo (IV) in pore water (Schlieker et al. 2001). However, the concentration of Mo in groundwater is controlled by redox conditions and the $\mathrm{pH}$ value. In the oxic waters at $\mathrm{pH}>5, \mathrm{Mo}$ occurs as the molybdate oxyanion $\left(\mathrm{MoO}_{4}\right.$ although it adsorbs readily to Fe oxides at low to neutral $\mathrm{pH}$ (Xu et al. 2006b) as well as to pyrite (Xu et al 2006) molybdate adsorbs to organic 


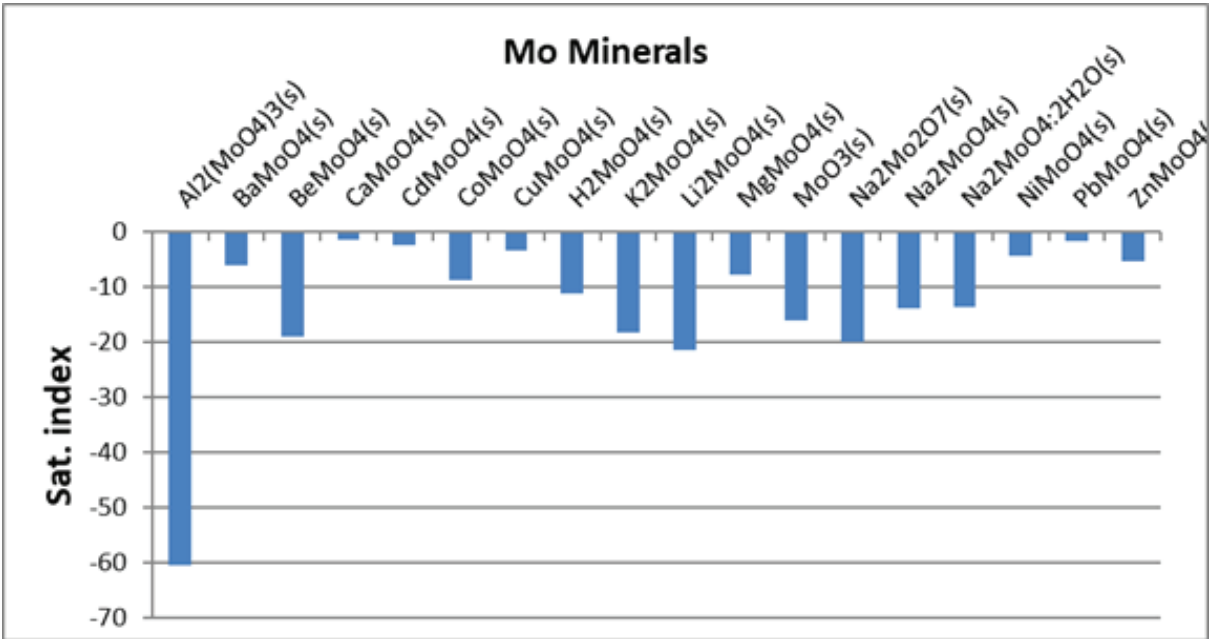

Fig. 9 - Saturation indices of different Mo species (average values for all 34 samples).

Fig. 9 - Indici di saturazione delle diverse specie di Mo (valori medi per tutti i 34 campioni). matter and clays (Wichard et al. 2009). In oxic alkaline conditions, molybdate is considered to be stable (Bruland and Lohan 2003).

Mo concentrations increased along the groundwater flow. The water samples collected from the two wells (T111) and (T113) in the northwestern part of the Wadi Al Arab well field showed the highest observed concentration of Mo which reaches $1439 \mu \mathrm{g} / \mathrm{L}$ and $648 \mu \mathrm{g} / \mathrm{L}$ respectively. This area with anomalous Mo values is the same where the phosphorite rocks are present (Abed et al. 2015). Thus, the two potential sources of Mo in groundwater in the study area are attributed to the presence of oilshale and phosphorites rocks within the carbonate aquifer matrix. In addition, the increase of Mo along groundwater flow direction can be related to other redoxcontrolled parameters. The redox changes are manifested by a sudden reduction in Eh and the concentration of DO which mark the location of a redox boundary following the onset of confined conditions (Smedley and Edmunds, 2002).

Many wells in the study area showed higher concentrations of Mo with low concentration of DO (Figure 10). This indicates that Mo concentrations are generally higher in anoxic and sub-oxic groundwater.

\section{Mo mobilization}

The Mo concentration in groundwater is strongly controlled by redox conditions and $\mathrm{pH}$. At $\mathrm{pH}>5$ Mo occurs mainly as the molybdate oxyanion in anoxic waters, $\left(\mathrm{MoO}_{4}{ }^{2-}\right)$ although this adsorbs readily to Fe oxides at low to neutral $\mathrm{pH}(\mathrm{Xu}$ et al. 2006b). The chemical affinity (charge, radius and ionic potential) of these heavy metals (Mo, Ni, Fe, Mn) show high similarity. So, the mobility and enrichment of these metals in the aquifer are mostly consistence with each other. However, these can be seen from the correlation of Mo with Mn, U, Ni (Figure 11, Figure 12 and Figure 13). Figure 11 shows a strong positive linear correlation between $\mathrm{Mo}$ and $\mathrm{Mn}(\mathrm{R} 2=0.73)$ indicating the same origin for these elements. In addition, $\mathrm{U}$ and $\mathrm{Ni}$ have a significant positive correlation with $\mathrm{Mo}$ ( $\mathrm{R} 2=0.73$ and 0.57 , respectively). The correlation between $\mathrm{Mo}$ and $\mathrm{Mn}, \mathrm{U}$ and $\mathrm{Ni}$ significant in spite of low correlation factor and this is due to a limited number of samples. Thus this relationship between the Mo and the other heavy metals may explain the released of Mo from the oil shale layers to groundwater.

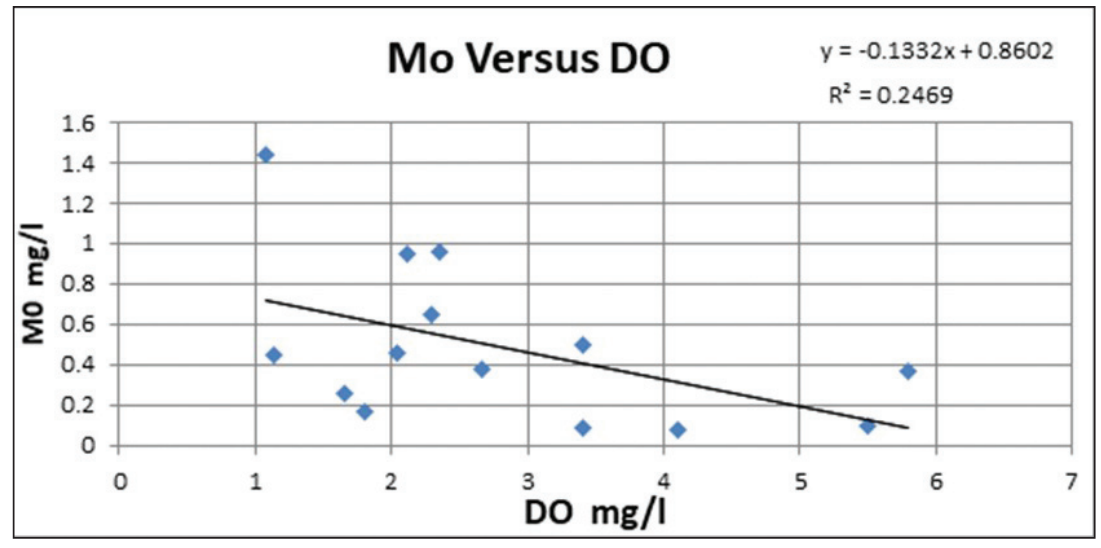

Fig. 10 - Correlation between Mo concentration and dissolved oxygen (DO) concentration.

Fig. 10 - Correlazione tra la concentrazione di Mo e l'ossigeno disciolto (DO). 

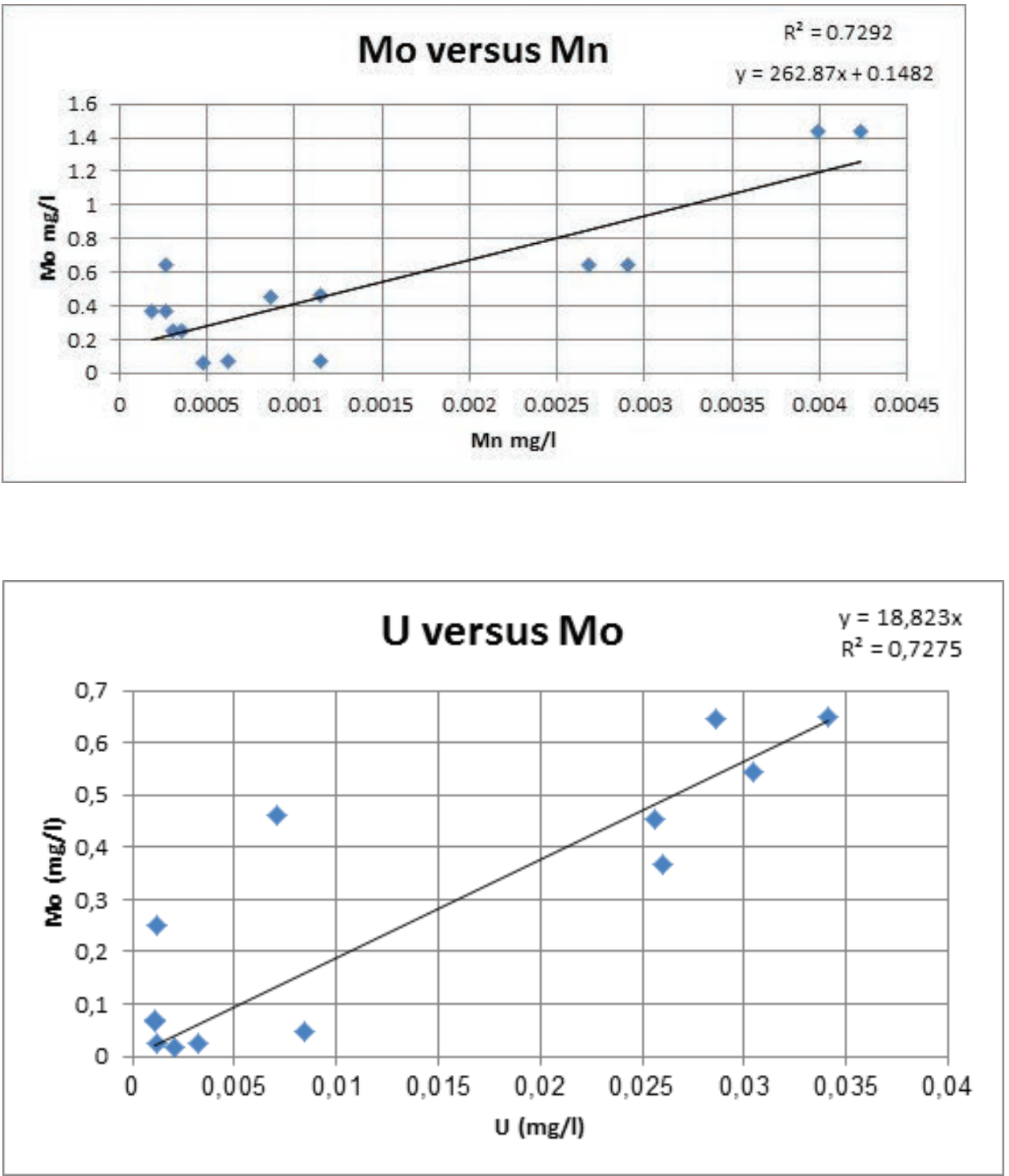

Fig. 12 - Correlation between Mo concentration and $U$ concentration.

Fig. 12 - Correlazione tra la concentrazione di Mo e la concentrazione di U.
Fig. 11 - Correlation between Mo concentration and $M n$ concentration.

Fig. 11 - Correlazione tra la concentrazione di Mo e la concentrazione di Mn.

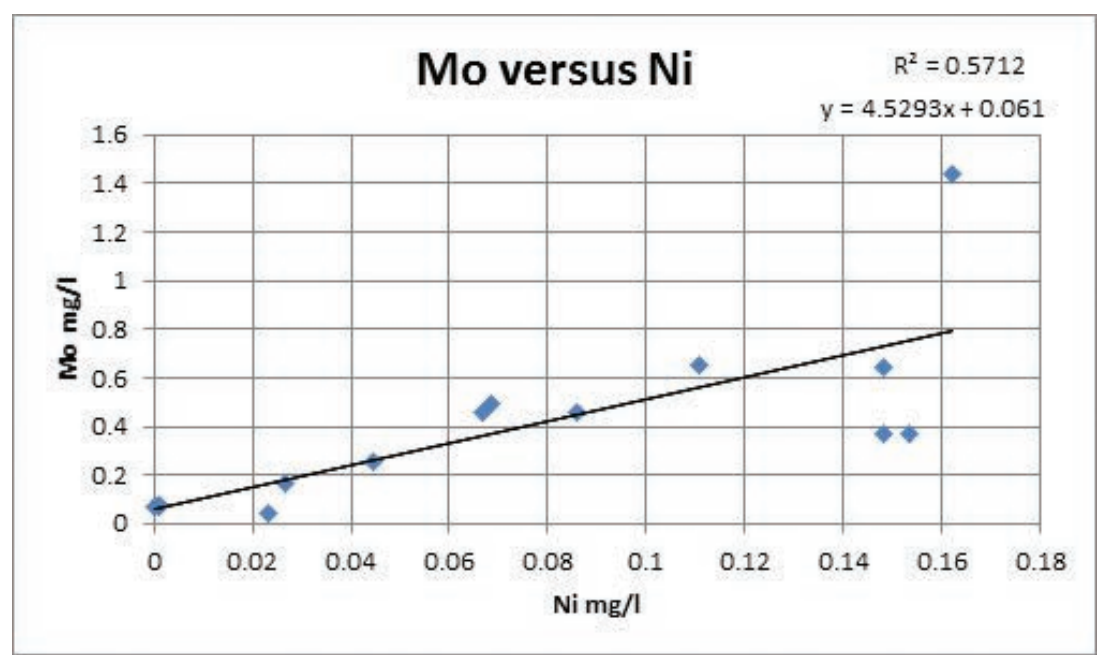

Fig. 13 - Correlation between Mo concentration and Ni concentration.

Fig. 13 - Correlazione tra la concentrazione di Mo e la concentrazione di Ni. 


\section{Conclusion}

It can be concluded that $70 \%$ of the groundwater samples of Wadi Al Arab catchment have high levels of Mo that exceed the permissible limits of $0.07 \mathrm{mg} / \mathrm{L}$ for drinking water according to JISM (2008) and WHO (2011) Guidelines. The Mo concentration ranges from 0.04 to $1.43 \mathrm{mg} / \mathrm{L}$, with an average value of $0.39 \mathrm{mg} / \mathrm{L}$. Furthermore, the concentrations of Mo increase along flow path of the groundwater towards northwestern part of the study area.

The current research shows that the concentration of Mo in groundwater is controlled by DO, Eh and $\mathrm{pH}$ values. According to the $\mathrm{pH}$-Eh stability diagram of Mo species, the molybdate $\left(\mathrm{MoO}_{4}^{-2}\right)$ is the dominant Mo species which accounts for $50 \%$. In addition, groundwater in the investigated area is characterized also by the presence of high concentrations of other heavy metals including $\mathrm{Sr}, \mathrm{Mn}, \mathrm{Fe}, \mathrm{As}, \mathrm{Ni}$ and $\mathrm{U}$.

A hydrogeochemical modeling approach has been introduced to identify the different Mo species in groundwater. It indicates the presence of 12 species of Mo where the dominant species was the molybdate $\left(\mathrm{MoO}_{4}^{-2}\right)$ which has a concentration of 2.3 x $10^{-6} \mathrm{~mol} / \mathrm{L}(0.37 \mathrm{mg} / \mathrm{L})$. And the lowest concentration was for the $\mathrm{Mo}_{8} \mathrm{O}_{26}{ }^{-4}$ (i.e., $2.55 \times 10^{-55} \mathrm{~mol} / \mathrm{L}$ ). In addition, by using the Visual Minteq software, the saturation indices of the Mo mineral species were calculated, which emphasize the undersaturated conditions. This indicates that the groundwater has short residence times and the natural equilibrium with Mo minerals was never reached. The Mo mineral species in the investigated wells are mostly soluble. The saturation index varies from -1.517 to -60.42 with an average value of -13.06 .

By linking the results of Mo concentrations in the groundwater and the results derived from the hydrogeochemical model, it can be concluded that that Mo concentration is influenced by natural sources. This is due to the presence of layers of oil shale and phosphorite rocks in the aquifer matrix. Therefore, these beds contain different minerals that contribute to dissolution of Mo mineral species in the rock and hence result in elevated concentration of Mo in groundwater due to water-rock interaction.

Acknowledgment: Thanks, and gratitude's are due to the Water Authority of Jordan for the support during water sampling from the well field and to the Hashemite University for providing logistic support. Also, many thanks to the Canadian Acme lab for analyzing the water samples. We will extend our gratitude to the anonymous reviewers for their valuable comments.

\section{REFERENCES}

Abed, A., Amireh, B., (1983) Petrography and geochemistry of some Jordanian oil shales from north Jordan. J. Pet. Geol. 5, 261e274. http://dx.doi.org/10.1111/ j.1747-5457.1983.tb00571.x.

Abed, A.M., Arouri, Z., Amiereh, D.S., Al-Hawari, Z., (2009) Characterization and genesis of some Jordanian oil shales. Dirasat Pure Sci. 36, 7e17.

Al Kuisi, M., Al-Hwaiti, M., Mashal, K., Abed, A.M., (2015) Spatial distribution patterns of Mo (Mo) concentrations in potable groundwater in Northern Jordan. Environ. Monit. Assess. 187, 148. http:// dx.doi.org/10.1007/s10661-015- 4264-5.

British Geological Survey (BGS) (2008) Mo in British drinking water: a review of source and occurrence and reconnaissance survey of concentration. Groundwater resources program, open report, OR/08/051.

Bruland KW, Lohan MC (2003) Controls of trace metals in seawater. In: Elderfield H (ed) The oceans and marine geochemistry. In: Holland HD, Turekian KK (exec eds) Treatise on geochemistry 6 Elsevier-Pergamon, Oxford, pp 23-47

Chappell WR, Meglen RR, Moure-Eraso R, Solomons CC, Tsongas TA, Walravens PA, Winston PW (1979) Human health effects of Mo in drinking water. US Environ Protect Agcy Rept 600/1-79006

Eisler, R. (2000) Handbook of chemical risk assessments: Health hazards to humans, plants, and animals [Electronic version]. Boca Raton, FL: CRC Press LLC.

Friberg L, Boston P, Nordberg G, Piscator M, Robert KH (1975) Mo-a toxicological appraisal. US Environ Protect Agcy Rep 600/1-75004

Harkness JS, Darrah TH, Moore MT, Whyte CJ, Mathewson PD, Cook T, Vengosh A. (2017) Naturally Occurring versus Anthropogenic Sources of Elevated Molybdenum in Groundwater: Evidence for Geogenic Contamination from Southeast Wisconsin, United States. Environ Sci Technol. Nov 7;51(21):12190-12199. doi: 10.1021/acs. est.7b03716.

Hem, J. D. (1989) Investigation Study and Interpretation of the Chemical Characteristics of Natural Water. United States Geological Survey Water-Supply Paper 2254. Third Edition.

Ibrahim, K. M. Khoury, H.N., Tuffaha R. (2016) Mo and Ni Removal from Drinking Water Using Zeolitic Tuff from Jordan. Minerals, 6, 116; DOI: $10.3390 / \min 6040116$.

JISM (Jordanian Institute of Standards and Metrology) (2008) Drinking water standards. Amman, No. 286/2008.

Langmuir D, 1997. Aqueous environmental geochemistry. Upper Saddle River, NJ: Prentice Hall.

Lourigan, J, Phelps W (2013) Caledonia groundwater Mo investigation southeast Wisconsin. Wisconsin Department of Natural Resources Published report $101 \mathrm{pp}$

Margana A (2006) Hydrogeological proposal for the delineation of a groundwater protection area for the Wadi Al Arab well field. Technical cooperation project MWI - BGR, Ministry of Water and Irrigation, Amman:

McEwan, A.G., and McDevitt, C.A. (2001) The DMSO reductase family of microbial Mo enzymes; molecular properties and role in the Dissimilatory reduction of toxic elements .Geomicrobiology journal, 19,3-21.

Ministry of Water and Irrigation (MWI), Water Budget: Projected Demands and Resources 2010-2025, 2012.

National Academy of Sciences (1989) Recommended dietary allowances, 10th ed. National Academy Press, Washington DC.

Rimawi O (1985) Hydrogeochemistry and isotope yydrology of the ground-and surface water in north Jordan (north-northeast of Mafraq, Dhuleil-Hallabat, Azraq-Basin, PhD Thesis, TU M_nchen, Germany. 
Schlieker, M., Schuring, J., Hencke, J., Schulz, H.D. (2001) The influence of redox processes on trace element mobility in a sandy aquifer--an experimental approach. J. Geochem. Explor. 73, 167-179.

Smedley P, Cooper D, Lapworth D (2014) Mo distributions and variability in drinking water from England and Wales. Environ Monit Assess 186:6403-6416

Smedley, P.L., Edmunds, W.M. (2002) Redox patterns and trace-element behavior in Stiefel EI (1996) Mo bolsters the bioinorganic brigade. Science 272:1599-1600

Smedley, P.L., Kinniburghb, D.G. (2017) Mo in natural waters: A review of occurrence, distributions and controls. Applied Geochemistry, 84, 2017, 387-432. https://doi.org/10.1016/j.apgeochem.2017.05.008

Thomas, M. A. (2007) The Association of Arsenic With Redox Conditions, Depth, and Ground-Water Age in the Glacial Aquifer System of the Northern United States. U.S. Geological Survey. Scientific Investigations Report 2007-5036.

Wang H, Gao J-e, Li X-h, Zhang S-l, Wang H-j (2015) Nitrate Accumulation and Leaching in Surface and Groundwater Based on Simulated Rainfall Experiments. PLoS ONE 10(8): e0136274. https:// doi.org/10.1371/journal.pone.0136274
WAJ (1989) Review of water resources development and use in Jordan. Ministry of water and Irrigation of Jordan, Amman.

Wedepohl KH (1995) The composition of the crust. Geochim Cosmochim Acta 59:1217-1232

WHO (1993) Guidelines for Drinking-Water Quality. Volume 1: Recommendations. (Second edition). (Geneva: World Health Organization.)

WHO (2011) Mo in drinking water. Background document for development of WHO Guidelines for Drinking-water Quality.World Health Organization, Geneva, Switzerland.

Wichard, T., Mishra, B., Myneni, S.C.B., Bellenger, J.P., Kraepiel, A.M.L., (2009) Storage and bioavailability of Mo in soils increased by organic matter complexation. Nature Geosci. 2, 625-629.

Xu, N., Christodoulatos, C., Braida, W., (2006a) Adsorption of molybdate and tetrathiomolybdate onto pyrite and goethite: Effect of $\mathrm{pH}$ and competitive anions. Chemosphere 62, 1726-1735.

Xu, N., Christodoulatos, C., Braida, W., (2006b) Modeling the competitive effect of phosphate, sulfate, silicate, and tungstate anions on the adsorption of molybdate onto goethite. Chemosphere 64, $1325-1333$ 